\title{
The Making of
}

European Private Law:

Why, How, What, Who 
(C) sellier european law publishers www.sellier.de 


\section{The Making of European Private Law: Why, How, What, Who}

edited by

Luigi Moccia

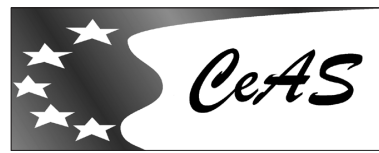


ISBN (print) 978-3-86653-258-8

ISBN (eBook) 978-3-86653-990-7

The Deutsche Nationalbibliothek lists this publication in the Deutsche Nationalbibliografie; detailed bibliographic data are available on the Internet at http://dnb.dnb.de.

(C) 2013 by sellier european law publishers $\mathrm{GmbH}$, Munich

All rights reserved. No part of this publication may be reproduced, translated, stored in a retrieval system or transmitted, in any form or by any means, electronic, mechanical, photocopying, recording or otherwise, without prior permission of the publisher.

Production: Karina Hack, Munich. Typesetting: fidus Publikations-Service GmbH, Nördlingen. Printing and binding: AZ Druck und Datentechnik GmbH, Kempten. Printed on acid-free, non-ageing paper. Printed in Germany. 